\title{
The Changing Business Landscape in Iran: Establishing Outsourcing Best Practices
}

\author{
Mohammadreza Akbari \\ Australian Institute of Business (AIB) \\ 27 Currie Street, SA 5000, Australia \\ Email: mohammadreza_akbari@yahoo.com (Corresponding Author) \\ John L. Hopkins \\ Swinburne University of Technology \\ PO Box 218, Hawthorn, VIC 3122, Australia \\ Email: jlhopkins@swin.edu.au
}

\begin{abstract}
During an evolutionary period for Iran the aim of this paper is to identify a set of success factors, to inform enterprises who are now able to engage in the practice of outsourcing after the recent removal of long-standing US and UN sanctions, and contribute towards the formulation of a set of guidelines to assist these organisations and help deepen the understanding of recent economic developments in the Middle East. Primary research data was collected using a selfadministered survey which required senior/executive managers from enterprises in Tehran to assess a set of outsourcing factors established by academic literature. The most important factors for achieving outsourcing success in Iran were found to be having a clear strategic vision and plan, understanding the intended use of outsourcing, and understanding how outsourcing aligns with organizational goals and objectives. The primary driver for adopting outsourcing is access to operational expertise and the sectors experiencing the greatest level of outsourcing success were the construction and IT industries. With little literature available on outsourcing in Iran this research addresses a clear gap in the current body of knowledge and contributes toward a deeper understanding of potential supply chain opportunities in this unique region. The findings will assist academic researchers, and contribute towards policy formation, and there are clear implications for Iranian enterprises who might be considering adopting outsourcing now that barriers permitting them from doing so have been removed.
\end{abstract}

Keywords: outsourcing, Iran, economic sanctions, business improvement, supply chain management.

\section{INTRODUCTION}

Economic sanctions on Iran were officially lifted in January 2016, six months after the UN Security Council signed a resolution (UN Security, 2015) that signaled the end for a set of long-standing international sanctions that restricted external cooperation with Iran on all foreign trade issues, financial services, energy sectors and technologies, which now opens up Iran to a multitude of business development opportunities in what is regarded as a potentially huge untouched market (Borger et al., 2015;
Paivar, 2015). As a result, according to Reuters, plans are already underway to rebuild an Oil and Gas industry that is predicted to be worth $\$ 185$ billion by 2020 (Nasralla \& Shehan, 2015). More recently, on $28^{\text {th }}$ January 2016, Airbus signed a huge deal with Iran to sell 118 passenger aircraft worth \$25bn, including twelve A380 superjumbos (Johnson, 2016).

The sanctions against Iran were originally put in place in 1979 and were designed to impede Iran's ability to borrow funds needed to finance its oil projects. In 2006 the UN set additional sanctions and, overall, it has been estimated that the total trade and financial sanctions have cost Iran around 1.1 per cent of its GDP, directly causing significant hindrance to their economic growth (Katzman, 2016; Yukhananov et al., 2015). Despite this, Iran still boasts the world's third largest petroleum treasury and the second largest gas reserves. The removal of these sanctions is predicted to signal a 'stampede of western business interests,' resulting in massive changes for Iranian businesses, both in terms of their ability to now engage with overseas partners and customers, as well as dealing with increased competition domestically, from new overseas competitors (Borger et al., 2015).

Due to the existence of an internal resource gap, and sanction-related constraints, a wide range of businesses in Iran experienced difficulties during the sanction period (Mendes \& Mahanty, 2014). According to Valmohammadi (2012), outsourcing is still infrequently used in Iranian organisations and, despite the recognition of its relevance and application in developed counties, only 25 per cent of the companies had so far implemented outsourcing. However, now that the sanctions are being lifted, it is more likely that the economic conditions in Iran will be far more stable, making it easier for Iranian enterprises to work with their overseas suppliers and vice versa. As a result of this change it is predicted that there will be an increase in outsourcing in Iran which will give rise to new supply chain opportunities. As outsourcing, and privatisation more generally, are still in their early phases in in this region it has emerged as a significant issue to be explored (Sedahi \& Davarzani, 2010; Valmohammadi, 2012). 
Many developing countries benefit from involvement in outsourcing, and participate in global supply chains, as an effective practice for meeting customer requirements and increasing overall customer satisfaction. However, companies in these regions face many different challenges than their counterparts in the likes of the US and Western Europe, due to the lack of maturity in their operational expertise and regulations, as highlighted by Msimangira \& Techa (2014) in their study of global supply chain practices and regulatory problems in Tanzania. The majority of previous research in this field has focused on the drivers and success factors (e.g. Assaf et al., 2012; Jain \& Natarajan, 2011; Beaumont \& Sohal, 2004; Koh Ser Mui, 2003), particularly in mature markets, whereas this study also includes two additional factors, the type and level of outsourcing, and is focussed specifically on developing best practices for an emerging market. Research into outsourcing practices in Iran, where a lack of detailed academic literature exists, could provide new insights into outsourcing best practices not only for Iran but potentially for other similar developing markets. The successful strategies we aim to identify in this study will provide invaluable guidelines, for Iranian enterprises looking to undertake outsourcing for the first time, whilst also informing companies who operate under similar conditions in other emerging regions. To tackle this issue, the researchers will attempt to answer the following research question:

RQ1 - With the imminent changes to the business climate in Iran, what are the best practices that enterprises must employ in order to achieve successful outsourcing?

To address RQ1 the researchers will first undertake a thorough examination of the current body of academic literature in this field, before presenting results from a selfadministrated survey that invited managers from the minority of Iranian enterprises that do currently practise outsourcing, to rate the importance of outsourcing factors and practices for enterprises.

\section{LITERATURE REVIEW}

\subsection{Business Practice in Iran}

The history of business privatisation in Iran dates back to the introduction of a law in 1975 pertaining that altered the shift of manufacturing units (Sedahi \& Davarzani, 2010). Following the Islamic Revolution of 1979, subarticle 32 of the First Development Plan became the first officially authorised fulcrum developed for adopting privatisation policies in the country (Rezaei, 2009). By the Islamic Revolution, the United States introduced sanctions against Iran which expanded in 1995 (Yukhananov et al., 2015). In 2006, after Iran refused to suspend its nuclear program, the United Nations Security Council (UNSC) imposed a new set of sanctions on Iran, followed by more from the European Union (EU) in 2007 (Yukhananov et al., 2015).

Despite these sanctions economic growth in Iran initially continued, "driven by government spending on priority sectors" until 2009 when conditions slowed due to the combination of the imposed sanctions, a reduction in oil value, home economic misconduct and mismanagement, inadequate oil revenue reserves, and the wider global financial crisis (Ilias, 2010).

As mentioned earlier Iran has the world's third major petroleum reserves, behind only Saudi Arabia and Canada, and also, after Russia, Iran boasts the world's second largest gas reserves (Katzman, 2016; Modarress, Ansari \& Thies, 2016). Consistent with Ilias (2010), in comparison to other countries located in Middle East and North Africa, Iran has the second largest population, after Egypt, and the region's second largest economy, behind Saudi Arabia. However, if you compare the most recent import and export data for Iran and Saudi Arabia it can be clearly seen that Iran is lagging some way behind economically.

Table 1 Iran and Saudi Arabia, Import and Export

\begin{tabular}{|c|c|c|c|c|c|}
\hline \multirow[b]{2}{*}{ Period } & \multirow[b]{2}{*}{$\begin{array}{l}\text { Trade } \\
\text { Flow }\end{array}$} & \multicolumn{2}{|c|}{ Iran } & \multicolumn{2}{|c|}{ Saudi Arabia } \\
\hline & & Partner & Trade Value & Partner & Trade Value \\
\hline \multirow{15}{*}{2011} & \multirow{7}{*}{ Export } & World & $\$ 130,543,999,999$ & World & $\$ 364,697,696,938$ \\
\hline & & Other Asia, nes & $\$ 61,361,311,101$ & Other Asia, nes & $\$ 197,734,717,301$ \\
\hline & & Other Europe, nes & $\$ 24,645,938,064$ & Areas, nes & $\$ 57,822,305,611$ \\
\hline & & Areas, nes & $\$ 9,328,538,864$ & $\begin{array}{l}\text { North America and Central } \\
\text { America, nes }\end{array}$ & $\$ 52,483,453,071$ \\
\hline & & China & $\$ 5,287,384,105$ & Other Europe, nes & $\$ 44,063,204,946$ \\
\hline & & Iraq & $\$ 4,646,790,449$ & Other Africa, nes & $\$ 6,836,636,279$ \\
\hline & & United Arab Emirates & $\$ 4,269,593,854$ & LAIA, nes & $\$ 4,695,901,870$ \\
\hline & \multirow{8}{*}{ Import } & World & $\$ 68,319,000,000$ & World & $\$ 131,586,577,550$ \\
\hline & & United Arab Emirates & $\$ 18,188,178,030$ & China & $\$ 17,176,499,071$ \\
\hline & & Areas, nes & $\$ 10,065,568,368$ & USA & $\$ 16,341,892,161$ \\
\hline & & China & $\$ 7,044,677,982$ & Germany & $\$ 8,973,801,084$ \\
\hline & & Rep. of Korea & $\$ 4,494,054,671$ & Japan & $\$ 8,238,943,099$ \\
\hline & & Germany & $\$ 3,927,406,067$ & Rep. of Korea & $\$ 7,705,938,966$ \\
\hline & & Turkey & $\$ 3,078,508,150$ & United Arab Emirates & $\$ 5,397,536,347$ \\
\hline & & Switzerland & $\$ 2,609,501,159$ & Italy & $\$ 4,540,638,476$ \\
\hline
\end{tabular}

Source: UN Comtrade Database (2016)

Whereas the trade value of Saudi's total exports in 2011 was US\$364.7 billion, and its imports were US\$131.6 billion, Iran's total exports and imports for the same period were only US\$130.5 billion and US\$68.3 billion 
respectively (See Table 1). The extent of the trade partnerships that Saudi Arabia has with North America, and parts of Europe, can clearly be seen. These are partnerships that Iran has been lacking, due to its long standing economic sanctions, but which may now be possible again.

The size of businesses in Iran range from small firms, with few employees and a very low turnover, up to large corporations, and the local Ministry of Economic Affairs and Finance (MEFA, 2009) defines the different size categories as follows; Small Firm (less than 50 employees), Medium Firm (between 51-500 employees), Large Firm (between 501-2500 employees), and Very Large Firm (more than 2500 employees).

\subsection{Outsourcing}

As business practices evolved over the past two decades, to a situation where markets have now become truly globalised (Cohen \& Russel, 2013; Willcocks, 2010), supply chain management and outsourcing emerged as key components of many globally-focussed business strategies (Christopher, 2016, Miah, Ahsan \& Msimangira, (2014); Pettersson \& Segerstedt, 2013; Willcocks, 2011). Outsourcing refers to the delegation of non-core business operations from inside production to outside specialists (Lysons \& Farrington, 2012; Quinn, 2000), and is defined as the practice of contracting out a process, such as manufacturing and development, to a third-party organisation (Lacity \& Willcocks, 2008; Oshri, Kotlarsky $\&$ Willcocks, 2015), and a key characteristic of outsourcing is the practice of off-shoring, outsourcing that process to a different country, which has long been recognised as an efficient strategic process for organisations wishing to remain competitive (Jones, 2009; Kang, Wu \& Hong, 2009; Mishra \& Mahanty, 2014).

In 1980s, the study of supply chain management (SCM) increased dramatically (Pettersson \& Segerstedt, 2013) and the expression 'outsourcing' was first used in reference to the delegation of work processes involving information systems (Lacity, Willcocks \& Rottman, 2008; Schniederjans et al., 2007). The expression has since evolved beyond information systems and is currently applied to all outsourced activities by any companies or organisations (Christopher, 2016; Lacity \& Rottman, 2009; Modarress, Ansari \& Thies, 2016), becoming an increasingly fashionable method of business development (Christopher, 2016; Willcocks, 2010). However, it must be noted that diverse outsourcing level practices between countries (Rasli Muslimen et al., 2012) and assessing the dimensions of the outsourcing market can be highly complex. Whilst an increasing use of outsourcing enabled some organisations to improve their overall business performance (Cohen \& Russel, 2013; Quinn, 2000), accomplish lower cost (Marquez-Ramos \& MartinesZarzoso, 2014) and better outcomes (Solakivi et al., 2011), it also made projects more complex. This has caused some organisations to rethink their decisions but it is worth mentioning, that even though outsourcing might be in decline in some locations to the extent where reshoring may have even occurred (Crooks, 2012; Sirkin et al., 2013; Ellram, Tate \& Petersen, 2013), the practice may still present a host of benefits for firms in Iran, where sanctions have rendered it largely untested.
Therefore, the identification of effective outsourcing practices is vital to companies considering employing it, particularly as only the most appropriate outsourcing methods typically lead an organisation to achieve their best performance (Cohen \& Russel, 2013; Quinn, 2000). An examination of the existing body of academic literature uncovers a diverse range of outsourcing characteristics and reveals there to be 3 diverse levels (Brown \& Wilson, 2005) and 3 distinct types (Oshri, Kotlarsky \& Willcocks, 2015) of outsourcing.

Levels of Outsourcing: According to Brown and Wilson (2005) the three different levels of outsourcing available to firms are tactical, strategical and transformational. A company should choose tactical outsourcing when they are faced with a specific problem as this level of outsourcing is regarded as a way to quickly tackle problems when a firm is already experiencing difficulties. Strategic outsourcing is a more advanced approach taken to 'maintain an organisations' premier value-creating actions' and its core competencies, whereas transformational outsourcing is a method that enables an organisation to respond to a changing market.

Types of Outsourcing: Analysis of the available literature reveals that outsourcing trends can also be categorised into three different types (Oshri, Kotlarsky \& Willcocks, 2015); total outsourcing is the transferring of more than 80 per cent of the company's business operating budget to an external provider; Selective outsourcing refers to sourcing a preferred function to single or numerous vendors, while managing between 20 to 80 per cent of business in-house; and Transitional outsourcing is the practice of temporarily outsourcing during a major transition for a company, such as bringing in a new technology.

Reasons for Outsourcing: Organisations outsource to lower the overall cost of a business function (Cohen \& Russel, 2013; Marquez-Ramos \& Martines-Zarzoso, 2014; Valmohammadi, 2012). Not all outsourcing is concerned with decreasing costs, but companies often outsource for reasons such as a critical financial position, or to reach company targets by increasing profits (Brown \& Wilson, 2005; Lysons \& Farrington, 2012). Outsourcing reduces costs of operation due to a shift from fixed to variable costs on company's income statement (Assaf et al., 2011; Koh Ser Mui, 2003). Outsourcing provides access to skills (Hansen, Muller \& Pottenger, 2008; Slack et al., 2015), and a sustainable foundation of talent, as a result of accessing third parties' information support (Koh Ser Mui, 2003). The organisation may achieve improvements in quality (Quinn, 2000; Sepehri, 2013) or performance via contracting out the service and it should be noticed as a possible improvement, to achieve higher service level (Assaf et al., 2011). Cost savings or reductions, cost restructuring access to skills (knowledge and experience) and improvements in quality appear to be the most popular reasons for outsourcing (Beaumont \& Sohal, 2004, Valmohammadi, 2012).

Outsourcing Success: It is necessary for all companies to understand how they can accomplish successful and effective outsourcing to achieve overall competiveness (Assaf et al., 2011; Brown \& Wilson, 2005; Christopher, 2016; Valmohammadi, 2012). Before creating any outsourcing agreement, it is necessary to perform an efficient needs analysis (Koh Ser Mui, 2003; Slack et al., 
2015). Having considered an organisation's objectives and goals (Seth, Goyal \& Kira, 2015), a strategic vision and business arrangement needs to be assessed, analysed, and clarified, with appropriate forecasting (Brown \& Wilson, 2005). It is a top-level management responsibility to come up with strategic objectives (Seth, Goyal \& Kira, 2015). Getting support from management (Christopher, 2016; Rasli Muslimen et al., 2012) and stakeholders and outsourcer attains some form of certification (such as ISO 9001, SEI, or CMM) ratings are therefore beneficial (Gonzalez, Gasco \& Llopis, 2005).

In summary, the findings from the literature have been grouped together in the following table according to the four main outsourcing characteristics; Reasons for Outsourcing, Outsourcing Success Elements, Types of Outsourcing and Levels of Outsourcing (see Table 2). These findings were utilized in the development of the questions for the questionnaire.

\subsection{Outsourcing in Iran}

In recent years a growing number of Iranian companies have expressed a desire to outsource a part their business function and a small number of academic studies have investigated aspects associated with the trend (Sepehri, 2013; Kamyabi \& Devi, 2011; Valmohammadi, 2012; Zomorrodi, 2014).

Sepehri (2013), developed a fundamental framework for supplier portfolio management, based on corporate and procurement strategies found in the Iranian Oil and Gas industry, and identified the importance of the timing and quality of goods and services. Kamyabi and Devi (2011), evaluated the factors affecting Iranian SMEs' decisions to outsourcing accounting functions, and identified a relationship between higher assets and a lower level of outsourcing, and between trust in external accounting and corporation strategy (Kamyabi \& Devi, 2011).

Moreover, Valmohammadi (2012) conducted a study that pinpoints 'Cost Savings', Cost reduction', and 'Capital investment reduction' as the top three drivers for implementing outsourcing in Iranian organisations. It also recognised 'poor transportation, non-standard road and IT infrastructure', 'Instability of economic condition', and losses of internal economics as the primary barriers for outsourcing in Iran (Valmohammadi, 2012). Similarly, research into the critical success factors for outsourcing in the Iranian automotive industry, highlighted the importance of 'Trust', 'Transaction Costs', 'Technology' and 'Supplied Product Quality’ (Zomorrodi, 2014).

Whilst this is an area that appears to be starting to attract a level of academic interest, there is very limited research currently available that establishes the best outsourcing practices for Iranian enterprises, and we see this as a relevant gap to address at this particular time. Research into outsourcing amongst Iranian enterprises, where outsourcing has not been widely adopted, can potentially provide new knowledge for companies hoping to benefit from this practice for the first time when the sanctions are lifted

Therefore, the aim of this study is to identify the outsourcing best practices of successful Iranian enterprises, and a survey will be utilised to address the following areas:
- Identify the types and levels of outsourcing currently practiced by Iranian enterprises.

- Identify the key reasons and success elements for Iranian enterprises adopting outsourcing.

- Identify any relationships between the reasons for outsourcing and outsourcing success.

- Test the validity of the findings from literature from Iranian enterprises context.

\section{RESEARCH METHODOLOGY}

A quantitative approach was taken with this research, with survey questionnaires being employed to extract primary data from practitioners, and answers proposing numeric explanations of developments or attitudes for a population through the study of a sample or that population. The questionnaire employed for in study was structured into five major sections (Screening Questions, Types and Levels of Outsourcing, Measurement of Reasons for Outsourcing and Success in Outsourcing, Company Information, and Demographics), and contained 43 questions in total, which were mostly of the Yes/No, multiple choice or five-point rating scale (Likert type) in nature. In support of the collection of data by this method, Fowler Jr (2014) suggests that, "special purpose surveys may be the only way to ensure that all the data needed for a given analysis are available and can be related" (Fowler Jr., 2014, p. 3). As established earlier, there is no existing data to call upon, so this method was seen as the most suitable for this purpose. Surveys are also well suited to gaining data about large samples of a population, are low in cost to administer, are inclusive in terms of the variables that are to be studied, and are appropriately designed for being able to make generalisations (Bell, 2013; Saunders, Lewis \& Thornhill, 2015).

Primary data was collected through the distribution of questionnaire surveys to a representative population sample of target respondents. The research questionnaires were self-administered to 100 companies, whose headquarters were in Tehran, as this is regarded to be most culturally accepted approach for collecting data in this area. Through known business associates and networks, the researcher identified the companies and requested introductions to these companies by telephone. In respect and politeness in line with Iranian business ethics and culture, it is important that an introduction has been made through known business associates and networks. The researcher requested permission to speak with respondents, arranged an appointment to meet with them, and invited them to complete the questionnaire in person. The participants that returned their responses by mail, in self-addressed envelopes provided, as per Iranian business ethics and culture the target population for the survey was enterprises in Tehran, that are involved in outsourcing activities, and the respondents were mostly Directors, CEOs and senior managers. 
Table 2 Summary of significant outsourcing factors according to current academic literature

\begin{tabular}{|c|c|c|}
\hline & Outsourcing Factors & Author/s \\
\hline $\begin{array}{l}\text { Levels of } \\
\text { Outsourcing }\end{array}$ & $\begin{array}{l}\text { Tactical outsourcing } \\
\text { Strategic outsourcing } \\
\text { Transformational outsourcing }\end{array}$ & Brown \& Wilson (2005) \\
\hline $\begin{array}{l}\text { Types of } \\
\text { outsourcing }\end{array}$ & $\begin{array}{l}\text { Total Outsourcing } \\
\text { Selective Outsourcing } \\
\text { Transitional outsourcing }\end{array}$ & Oshiri, Kotlarsky \& Willcocks (2015) \\
\hline $\begin{array}{l}\text { Reasons for } \\
\text { outsourcing }\end{array}$ & $\begin{array}{l}\text { Cost Saving } \\
\text { Cost restructuring } \\
\text { Improvements in quality } \\
\text { Contract } \\
\text { Operational expertise } \\
\text { Access to wider knowledge and experience } \\
\text { Staffing issues } \\
\text { Capacity management } \\
\text { Catalysts for change } \\
\text { Reduced time to market } \\
\text { Commodification } \\
\text { Risk management } \\
\text { Time zone rationalisation } \\
\text { Customer pressure }\end{array}$ & $\begin{array}{l}\text { Cohen \& Russel (2013); Marquez-Ramos \& Martines-Zarzoso } \\
\text { (2014) } \\
\text { Brown \& Wilson (2005); Koh Ser Mui (2003) } \\
\text { Quinn (2000), Sepehri (2013) } \\
\text { Assaf et al. (2011) } \\
\text { Oshri, Kotlarsky \& Willcocks (2015); Slack et al. (2015) } \\
\text { Hansen, Muller \& Pottenger (2008); Slack et al. (2015) } \\
\text { Assaf et al. (2011); Beaumont \& Sohal (2004) } \\
\text { Beaumont \& Sohal (2004); Brown \& Wilson (2005); Sepehri } \\
\text { (2013) } \\
\text { Brown \& Wilson (2005); Koh Ser Mui (2003) } \\
\text { Manning, Massini \& Lewin (2008) } \\
\text { Brown \& Wilson (2005) } \\
\text { Oshri, Kotlarsky \& Willcocks (2015); Valmohammadi (2012) } \\
\text { Koh Ser Mui (2003); Valmohammadi (2012) } \\
\text { Beaumont \& Sohal (2004) }\end{array}$ \\
\hline $\begin{array}{l}\text { Outsourcing } \\
\text { success }\end{array}$ & $\begin{array}{l}\text { Conducting a needs analysis prior to making the outsourcing } \\
\text { decision } \\
\text { Clearly defining terms and conditions in the outsourcing } \\
\text { contract } \\
\text { Having a strategic vision and plan, and an understanding of } \\
\text { the intended use of outsourcing } \\
\text { Outsourcer understanding the organisation's goals and } \\
\text { objectives } \\
\text { Appropriate outsource selection procedures } \\
\text { Determining which areas of your company you would like to } \\
\text { outsource } \\
\text { On-going management of relationships and communication } \\
\text { Properly drawn up contracts } \\
\text { Outsourcer attains some form of certification such as ISO } \\
9001, \text { SEl, or CMM rating } \\
\text { Top management's support and involvement } \\
\text { Careful attention to personnel issues and conducting open } \\
\text { communication with the affected individual or group } \\
\text { Financial planning and analysis } \\
\text { Establishing trust between organisation and outsourcer } \\
\text { Criteria drawn up to measure the outsourcer's performance }\end{array}$ & $\begin{array}{l}\text { Oshri, Kotlarsky \& Willcocks (2015); Slack et al. (2015) } \\
\text { Brown \& Wilson (2005); Koh Ser Mui (2003) } \\
\text { Assaf et al. (2011); Brown \& Wilson (2005) } \\
\text { Seth, Goyal \& Kira (2015); Koh Ser Mui (2003) } \\
\text { Assaf et al. (2011) } \\
\text { Brown \& Wilson (2005) } \\
\text { Christopher (2016); Oshri, Kotlarsky \& Willcocks (2015) } \\
\text { Brown \& Wilson (2005) } \\
\text { Gonzalez, Gasco \& Llopis (2005) } \\
\text { Christopher (2016); Rasli Muslimen et al. (2012) } \\
\text { Koh Ser Mui (2003) } \\
\text { Cohen \& Russel (2013) } \\
\text { Christopher (2016); Msimangira \& Tesha (2014) } \\
\text { Brown \& Wilson (2005); Koh Ser Mui (2003) }\end{array}$ \\
\hline
\end{tabular}

In total, 79 completed questionnaires were returned, with 74 of these being usable for analysis. The remaining 5 copies were not functional as a result of missing data in their responses. This indicates a 74 per cent response rate. During data coding into SPSS, 43 companies were excluded because they were identified as not successful in outsourcing process. After coding, there were 31 usable responses present in the database. The raw data was coded using SPSS and treated with the descriptive analysis, factor analysis, correlation analysis, cross-tabulation, and means methods previously employed by Beaumont and Sohal (2004) to explore outsourcing decision making in Australia. Factor analysis with a Varimax rotation method was implemented in clustering the items into separate reasons for 'outsourcing adoption' and 'success in outsourcing' categories. Through factor analysis, Principal component analysis was used for extraction and Varimax with Kaiser Normalization rotations. Finally, the relative importance index (RII) method of analysis, as employed in the study by Sambasivan and Yau (2007), was also adopted by this research as a proven method for arranging variables on the basis of their 'importance, agreement, (or) severity' etc. (Holt, 2014).

\section{RESULTS}

The results of the empirical work conducted are presented in the following section. Firstly, some general demographic effects of the Iranian enterprises undertaking successful outsourcing operations are discussed, such as size and scope of organisation and outsourcing success ratio, before focus is drawn to the most commonly practiced outsourcing factors and the inherent relationships that lead to success. 


\subsection{Demographic Effect}

The survey requested demographic information relating to the responding companies (Table $\mathbf{3}$ and Figure 1-2): size of organisation (expressed as number of employees), Length of employment with current organisation, and Respondent's role in the organisation. On analyzing Table 1 it can be seen that the vast majority of the respondents were from medium size companies with 51 to 500 employees, with only 12.9 per cent of companies studied having 50 or less employees.

Table 3 Size of organisation

\begin{tabular}{lccc}
\hline & Frequency & $\%$ & Cumulative precents \\
\hline Less than 50 & 4 & 12.9 & 12.5 \\
$51-500$ & 17 & 54.9 & 35.5 \\
More than 500 & 10 & 32.2 & 100.0 \\
Total & 31 & 100.0 & \\
\hline
\end{tabular}

Figure 1 looks at the length of employment that the participants had spent with their current organisations, and illustrates that fact that 42 per cent $(n=13)$ of respondents had only 1-3 or 4-6 year's tenure with their current organisation, with only 16 per cent $(n=5)$ having been with their current organisation for more than 6 years in. Examining the roles that the participants (see Figure 2) held within those organisations revealed that 90 per cent $(n=28)$ were in either directorial, CEO, middle management, or senior management positions, with 10 per cent $(n=3)$ holding IT/IS managerial roles.

\subsection{Outsourcing Factors}

The relative importance index (RII) was computed for each of the outsourcing factors in order to identify the most significant reasons for outsourcing, the level and type of outsourcing practiced, and the outsourcing success elements. The outsourcing factors were ranked based on 'RII' values. From the rankings assigned to each of the characteristics it was possible to identify the most important reasons for outsourcing, the level and types of outsourcing being practiced, and the success elements for Iranian enterprises conducting outsourcing.

Reasons for Outsourcing: Respondents were asked to rate the importance of 14 reasons for outsourcing that were drawn from the literature. Referring to Table $\mathbf{3}$ and based on 'RII', the three most significant reasons for outsourcing, as perceived by respondents from Iranian enterprises, were: (1) Operational expertise ( $\mathrm{RII}=0.819$ / Mean=4.096); (2) Wider experience and knowledge (RII=0.794 / Mean=3.967); (3) Cost restructuring (RII=0.787 / Mean=3.935). The factor analysis of the responses is presented in Table 4 (Principal component analysis was used for extraction and Varimax with Kaiser Normalization rotations).

Factor analysis was performed on 14 different elements relating to the reasons supporting the outsourcing's scope, as per the questionnaire. The theory of component analysis is that it is able to issue the elements and to categorise the dimensions within the reasons behind outsourcing. From the analysis, as shown in Table 4, it was established that there are four interpretable support factors that denote the reasons why Iranian enterprises decided to adopt outsourcing:

Adoption Factor 1: Access to a larger talent pool and a sustainable of skills, Operational expertise, Capacity management, Provide a legal binding contract, and Time zone.

Adoption Factor 2: Reduce time to market, Improve quality, and wider knowledge and experience.

Adoption Factor 3: Cost restructuring, Cost savings, and Catalyst for change

Adoption Factor 4: Reduce Customer pressure, Risk Management, and allows a wide range of businesses access to services.

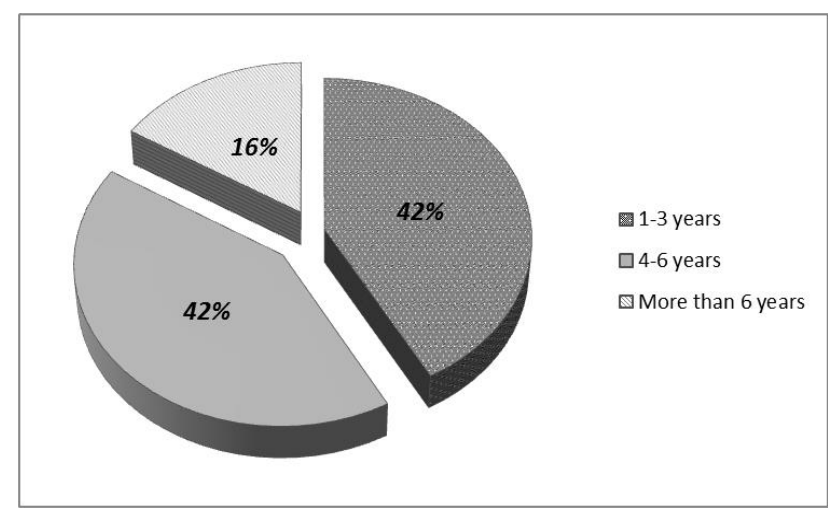

Figure 1 Length of employment with current organisation

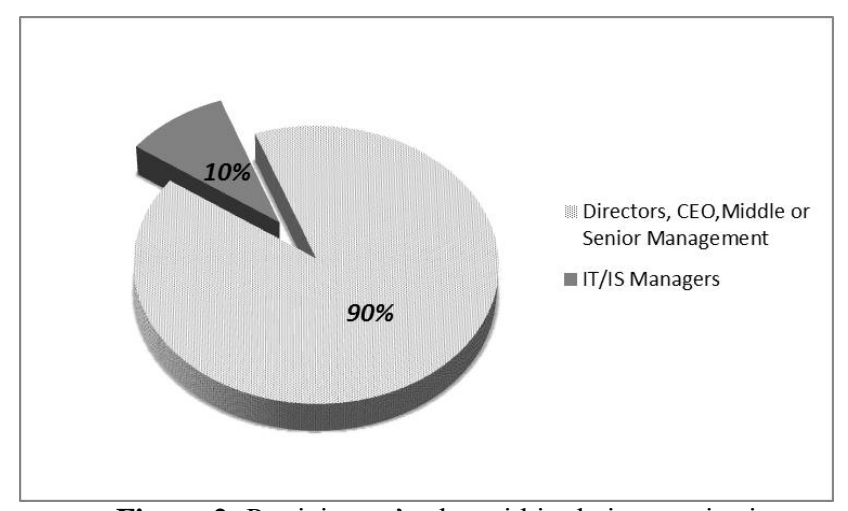

Figure 2: Participants' roles within their organisation

Table 4 RII and factor analysis of reasons for outsourcing

\begin{tabular}{|c|c|c|c|c|c|c|c|c|}
\hline \multirow{2}{*}{ Reasons for outsourcing (Adoption Factors) } & \multicolumn{2}{|c|}{ RII } & \multicolumn{2}{|c|}{ Statistics } & \multicolumn{4}{|c|}{ Factors analysis component } \\
\hline & Rank & Value & $N$ & Mean & 1 & 2 & 3 & 4 \\
\hline Access to a larger talent pool and a sustainable of skills & 4 & 0.781 & 31 & 3.903 & .835 & & & \\
\hline Operational expertise & 1 & 0.819 & 31 & 4.096 & .775 & & & \\
\hline Capacity management & 4 & 0.781 & 31 & 3.903 & .720 & & & \\
\hline Provide a legal binding contract & 5 & 0.774 & 31 & 3.871 & .681 & & & \\
\hline Time zone & 11 & 0.645 & 31 & 3.225 & .488 & & & \\
\hline Reduce time to market & 10 & 0.690 & 31 & 3.580 & & .921 & & \\
\hline Improve quality & 7 & 0.761 & 31 & 3.806 & & .846 & & \\
\hline Wider knowledge and experience & 2 & 0.794 & 31 & 3.967 & & .588 & & \\
\hline Catalyst for change & 6 & 0.767 & 31 & 3.838 & & & .844 & \\
\hline
\end{tabular}


Table 4 RII and factor analysis of reasons for outsourcing (con't)

\begin{tabular}{|c|c|c|c|c|c|c|c|c|}
\hline \multirow[b]{2}{*}{ Reasons for outsourcing (Adoption Factors) } & \multicolumn{2}{|c|}{ RII } & \multicolumn{2}{|c|}{ Statistics } & \multicolumn{4}{|c|}{ Factors analysis component } \\
\hline & Rank & Value & $N$ & Mean & 1 & 2 & 3 & 4 \\
\hline Cost restructuring & 3 & 0.787 & 31 & 3.935 & & & .830 & \\
\hline Cost savings & 7 & 0.761 & 31 & 3.806 & & & .804 & \\
\hline Reduce Customer pressure & 10 & 0.690 & 31 & 3.451 & & & & .835 \\
\hline Risk Management & 10 & 0.690 & 31 & 3.451 & & & & .685 \\
\hline Allows a wide range of businesses access to services & 8 & 0.748 & 31 & 3.741 & & & & .627 \\
\hline
\end{tabular}

\subsection{Outsourcing Success Elements}

Derived from 'RII', the three most significant success elements of outsourcing as perceived by respondents were: (1) having a strategic vision and plan, and understand the intended use of outsourcing (RII=0.916/Mean=4.580); (2) Outsourcer understands the organisation's goals \& objectives (RII=0.903/Mean=4.516); (3) Conduct a need analysis prior to making the outsourcing decision (RII=0.884/Mean=4.419). The factor analysis of responses is reported in Table 5 (Principal component analysis was used for extraction and Varimax with Kaiser Normalisation rotations).

Factor analysis was also performed on the 14 success elements from the questionnaire. This analysis suggested that there are four principal factors for success in outsourcing:

Success Factor 1: Conduct a need analysis prior to making the outsourcing decision, having a strategic vision and plan, and understanding the intended use of outsourcing, clearly defined terms and conditions in the outsourcing contract, appropriate outsource selection procedures, and ongoing management of the relationships and communication.

Success Factor 2: Criteria are drawn up to measure the outsourcer's performance, properly drawn up contact, and top management's support \& involvement.

Success Factor 3: Financial planning and analysis, careful attention to the personnel issues \& conducting open communication with the affected individual/group, and seek to establish trust between organisation and outsourcer.

$\underline{\text { Table } 5 \text { RII and factor analysis for outsourcing success elements }}$

\begin{tabular}{|c|c|c|c|c|c|c|c|c|}
\hline \multirow[t]{2}{*}{ Outsourcing success elements } & \multicolumn{2}{|c|}{ RII } & \multicolumn{2}{|c|}{ Statistics } & \multicolumn{4}{|c|}{$\begin{array}{l}\text { Factors analysis } \\
\text { component }\end{array}$} \\
\hline & Rank & Value & $N$ & Mean & 1 & 2 & 3 & 4 \\
\hline Conduct a need analysis prior to making the outsourcing decision & 3 & 0.884 & 31 & 4.419 & .833 & & & \\
\hline Having a strategic vision \& plan, and understanding the intended use of outsourcing & 1 & 0.916 & 31 & 4.580 & .827 & & & \\
\hline Clearly defined terms \& conditions in the outsourcing contract & 5 & 0.865 & 31 & 4.322 & .788 & & & \\
\hline Appropriate outsource selection procedures & 10 & 0.826 & 31 & 4.129 & .589 & & & \\
\hline Ongoing management of the relationships \& communication & 8 & 0.839 & 31 & 4.193 & .514 & & & \\
\hline Criteria are drawn up to measure the outsourcer's performance & 10 & 0.826 & 31 & 4.129 & & .886 & & \\
\hline Properly drawn up contact & 9 & 0.832 & 31 & 4.161 & & .812 & & \\
\hline Top management's support \& involvement & 4 & 0.871 & 31 & 4.354 & & .503 & & \\
\hline Financial planning and analysis & 7 & 0.845 & 31 & 4.225 & & & .890 & \\
\hline $\begin{array}{l}\text { Careful attention to the personnel issues \& conducting open communication with the affected } \\
\text { individual/group }\end{array}$ & 6 & 0.852 & 31 & 4.258 & & & .845 & \\
\hline Seek to establish trust between organisation and outsourcer & 6 & 0.852 & 31 & 4.258 & & & .629 & \\
\hline Outsourcer attains some form of certification such as ISO 9001, SEI, CMM rating & 11 & 0.787 & 31 & 3.935 & & & & .866 \\
\hline Outsourcer understands the organisation's goals \& objectives & 2 & 0.903 & 31 & 4.516 & & & & .725 \\
\hline Determine which areas of your company you would like to outsource & 10 & 0.826 & 31 & 4.129 & & & & .590 \\
\hline
\end{tabular}

Success Factor 4: Outsourcer attains some form of certification such as ISO 9001, SEI, CMM rating, outsourcer understands the organisation's goals and objectives, and determine which areas of your company you would like to outsource.

\subsection{Type of Outsourcing}

Based on 'RII' (Table 6), 'selective outsourcing' was identified as the most significant type of outsourcing ( $\mathrm{RII}=0.881$ ) practiced amongst Iranian enterprises, followed by 'transitional Outsourcing' $(\mathrm{RII}=0.731)$ and 'total outsourcing' (RII=0.548).

\subsection{Level of Outsourcing}

Derived from 'RII' (Table 6), 'strategic outsourcing' was acknowledged as the most important level of outsourcing $(\mathrm{RII}=0.827)$ followed by 'tactical outsourcing' $(\mathrm{RII}=0.752)$ and 'transformational outsourcing' (RII=0.709)

\subsection{Outsourcing Reasons and Success Elements vs. Type and Level of Outsourcing}

The reasons for adopting outsourcing, and the outsourcing success elements, have been separated according to the type and level of outsourcing present. Based on the reasons for outsourcing and outsourcing 
success elements, the 'mean' value for each of the four divided factors for outsourcing reasons and success elements for the various levels and types of outsourcing was obtained. This allowed a study of the position of respondents, based on their observations (Table 7).

\subsection{Correlation between Reasons for Outsourcing and Outsourcing Success Elements}

Pearson correlation was carried out for all the variables, which included four variables that existed in the reasons for outsourcing and outsourcing success elements.

Table 8, highlights a significant relationship between 'Success Factor 4' and 'Adoption Factor 1'. The more accurate this information, the better they can achieve an outsourcing business process in a successful condition. And if the company conduct a need analysis prior to making the outsourcing decision, and understand the intended use of outsourcing combine with clear vision \& plan can lead to accomplish a superior global competitiveness. In summary, it was confirmed that there are relationships between outsourcing characteristics in the Iranian enterprises.

Table 6 Type and level of outsourcing

\begin{tabular}{|c|c|c|c|c|}
\hline & & RII & $\mathbf{N}$ & Mean \\
\hline \multirow{3}{*}{ 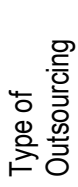 } & Selective Outsourcing & 0.881 & 31 & 2.645 \\
\hline & Transitional Outsourcing & 0.731 & 31 & 2.193 \\
\hline & Total Outsourcing & 0.548 & 31 & 1.645 \\
\hline \multirow{3}{*}{ 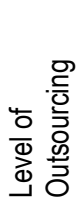 } & Tactical Outsourcing & 0.752 & 31 & 2.258 \\
\hline & Strategic Outsourcing & 0.827 & 31 & 2.483 \\
\hline & Transformational Outsourcing & 0.709 & 31 & 2.129 \\
\hline
\end{tabular}

Table 7 Mean value of reasons and success elements for types and levels of outsourcing

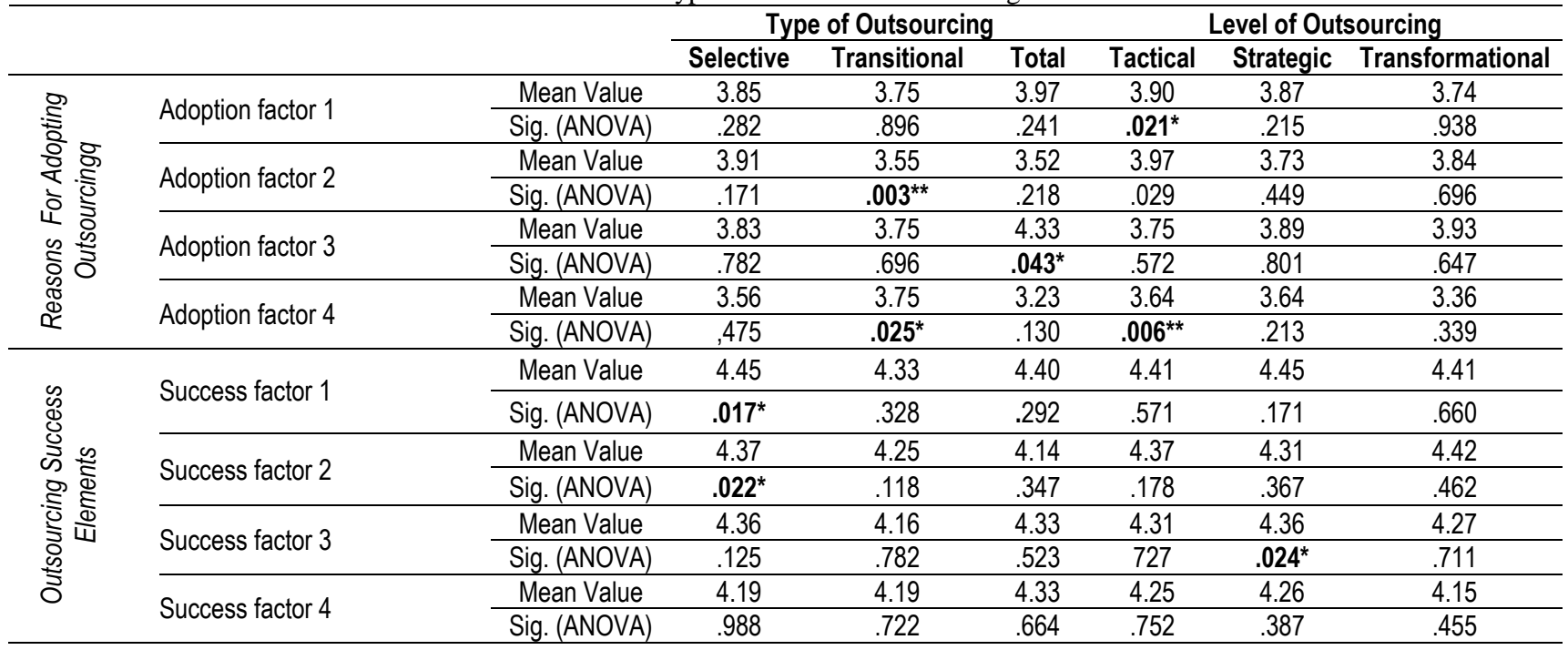

$\underline{\text { Table } 8 \text { Correlation between outsourcing success elements and reasons for outsourcing }}$

\begin{tabular}{|c|c|c|c|c|c|}
\hline & & $\begin{array}{l}\text { Outsourcing Factor } \\
1\end{array}$ & $\begin{array}{l}\text { Outsourcing Factor } \\
2\end{array}$ & $\begin{array}{c}\text { Outsourcing Factor } \\
3\end{array}$ & $\begin{array}{c}\text { Outsourcing Factor } \\
4\end{array}$ \\
\hline \multirow{2}{*}{ Success Factor 1} & Pearson Correlation & .139 & .041 & -.022 & .204 \\
\hline & Sig. & .229 & .413 & .453 & .135 \\
\hline \multirow{2}{*}{ Success Factor 2} & Pearson Correlation & .086 & .237 & .244 & .141 \\
\hline & Sig. & .323 & .100 & .083 & .224 \\
\hline \multirow{2}{*}{ Success Factor 3} & Pearson Correlation & .013 & .094 & .286 & -.031 \\
\hline & Sig. & .473 & .308 & .060 & .434 \\
\hline \multirow{2}{*}{ Success Factor 4} & Pearson Correlation & $.339^{*}$ & .018 & .178 & -.009 \\
\hline & Sig. & .031 & .462 & .170 & .482 \\
\hline
\end{tabular}

\section{*. Correlation is significant at the 0.05 level}

\subsection{Successful Outsourcing vs. Type of Organization}

As part of this research it was important to identify the successful cases, in terms of the individual companies themselves as well as the industries which they represented. In order to achieve this, the data used in this research was collected from a range of enterprises in different industries, with a cross-tabulation analysis then being performed. More specifically, respondents' answers to the survey questions asking about their particular type of industry and level of success with outsourcing were the inputs for the crosstabulation analysis. This revealed that the greatest level of success with outsourcing, amongst our cohort of Iranian enterprises, were experienced in the Construction, where 5 out of 7 respondents (71.4 per cent) and IT industry, where 9 companies out of 16 respondents (56.2 per cent) reported that had been successful (Figure 3 \& 4). The least successful industries for outsourcing were found to be that of banking, with no successful cases were reported. 


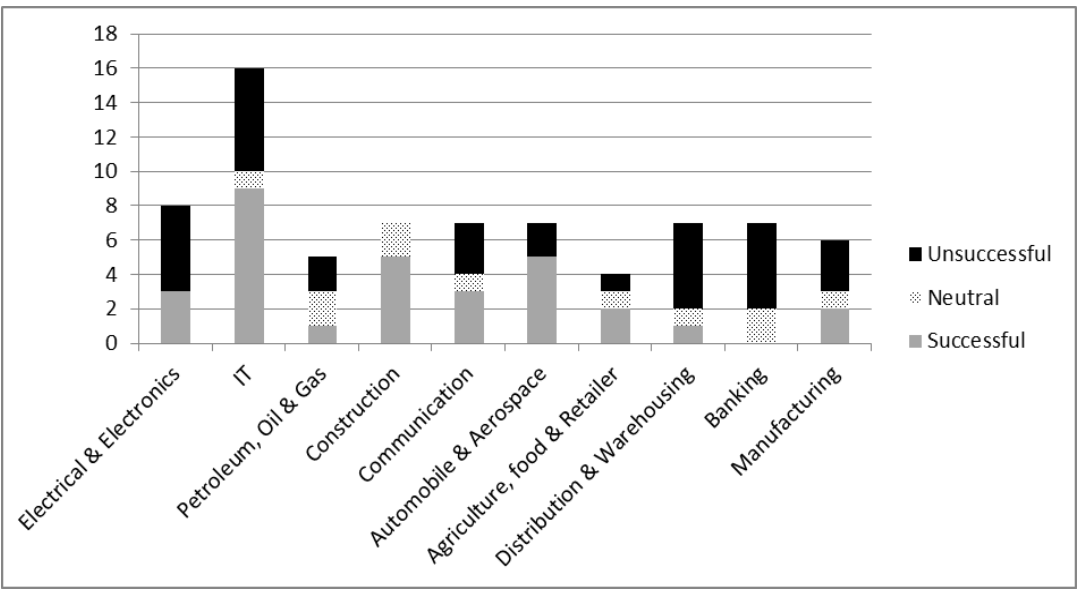

Figure 3 Successful, Neutral and Unsuccessful

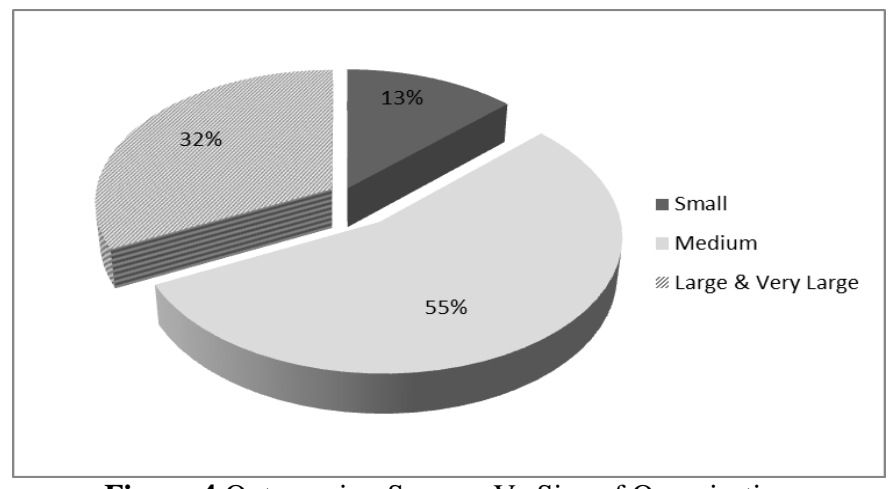

Figure 4 Outsourcing Success Vs Size of Organisation

\subsection{Outsourcing Factors vs. Size of Organisations}

In regard to aim of the study, outsourcing factors were separated according to the size of organisations (Table 9, 10 and 11). Based on the size of organisations, RII analysis for each factor was undertaken to examine the links between the size of organisations and their perception of outsourcing factors.

Referring to Table 9 and based on 'RII', the most significant reasons for outsourcing, as perceived by respondents from Iranian enterprises, were:

- Small firms: Operational expertise

- $\quad$ Medium firms: Access to a larger talent pool and a sustainable of skills, Operational expertise, and Wider knowledge and experience.

- $\quad$ Large and Very Large firms: Cost restructuring, and Cost savings
Derived from 'RII' in Table 10, the most significant success elements of outsourcing as perceived by respondents were:

- Small firms: Financial planning and analysis, Careful attention to the personnel issues \& conducting open communication with the affected individual/group, and Outsourcer understands the organisation's goals \& objectives.

- Medium firms: Having a strategic vision \& plan, and understanding the intended use of outsourcing.

- Large and Very Large firms: Properly drawn up contact, and Top management's support \& involvement.

Lastly, Table 11 shows total outsourcing is also ranked 1 amongst small firms and transformational outsourcing score the highest rank amongst Large and Very large firms.

Table 9 RII Analysis of reasons for outsourcing vs size of organisation (top three)

\begin{tabular}{|c|c|c|c|c|c|c|}
\hline \multirow[b]{2}{*}{ Adoption Factors } & \multicolumn{2}{|c|}{ Small } & \multicolumn{2}{|c|}{ Medium } & \multicolumn{2}{|c|}{ Large \& Very Large } \\
\hline & Rank & Value & Rank & Value & Rank & Value \\
\hline Access to a larger talent pool and a sustainable of skills & & & 1 & 0.811 & & \\
\hline Operational expertise & 1 & 0.900 & 1 & 0.811 & & \\
\hline \multicolumn{7}{|l|}{ Capacity management } \\
\hline Provide a legal binding contract & 2 & 0.850 & & & & \\
\hline \multicolumn{7}{|l|}{ Time zone } \\
\hline \multicolumn{7}{|l|}{ Reduce time to market } \\
\hline Improve quality & & & & & 2 & 0.820 \\
\hline Wider knowledge and experience & & & 1 & 0.811 & & \\
\hline
\end{tabular}


Table 9 RII Analysis of reasons for outsourcing vs size of organisation (top three) (con't)

\begin{tabular}{|c|c|c|c|c|c|c|}
\hline \multirow[b]{2}{*}{ Adoption Factors } & \multicolumn{2}{|c|}{ Small } & \multicolumn{2}{|c|}{ Medium } & \multicolumn{2}{|c|}{ Large \& Very Large } \\
\hline & Rank & Value & Rank & Value & Rank & Value \\
\hline Catalyst for change & 2 & 0.850 & & & & \\
\hline Cost restructuring & & & & & 1 & 0.840 \\
\hline Cost savings & & & & & 1 & 0.840 \\
\hline \multicolumn{7}{|l|}{ Reduce Customer pressure } \\
\hline \multicolumn{7}{|l|}{ Risk Management } \\
\hline Allows a wide range of businesses access to services & & & & & & \\
\hline
\end{tabular}

Table 10 RII Analysis of outsourcing success elements vs size of organisation (top three)

\begin{tabular}{|c|c|c|c|c|c|c|}
\hline \multirow{2}{*}{ Adoption Factors } & \multicolumn{2}{|c|}{ Small } & \multicolumn{2}{|c|}{ Medium } & \multicolumn{2}{|c|}{ Large \& Very Large } \\
\hline & Rank & Value & Rank & Value & Rank & Value \\
\hline Conduct a need analysis prior to making the outsourcing decision & & & 2 & 0.894 & & \\
\hline $\begin{array}{l}\text { Having a strategic vision \& plan, and understanding the intended use of } \\
\text { outsourcing }\end{array}$ & & & 1 & 0.941 & 2 & 0.900 \\
\hline \multicolumn{7}{|l|}{ Clearly defined terms \& conditions in the outsourcing contract } \\
\hline \multicolumn{7}{|l|}{ Appropriate outsource selection procedures } \\
\hline \multicolumn{7}{|l|}{ Ongoing management of the relationships \& communication } \\
\hline \multicolumn{7}{|l|}{ Criteria are drawn up to measure the outsourcer's performance } \\
\hline Properly drawn up contact & & & & & 1 & 0.920 \\
\hline Top management's support \& involvement & & & & & 1 & 0.920 \\
\hline Financial planning and analysis & 1 & 0.950 & & & & \\
\hline $\begin{array}{l}\text { Careful attention to the personnel issues \& conducting open communication with } \\
\text { the affected individual/group }\end{array}$ & 1 & 0.950 & & & & \\
\hline \multicolumn{7}{|l|}{ Seek to establish trust between organisation and outsourcer } \\
\hline \multicolumn{7}{|l|}{$\begin{array}{l}\text { Outsourcer attains some form of certification such as ISO 9001, SEI, CMM } \\
\text { rating }\end{array}$} \\
\hline Outsourcer understands the organisation's goals \& objectives & 1 & 0.950 & 2 & 0.894 & & \\
\hline
\end{tabular}

Table 11 RII Analysis of outsourcing types and levels vs size of organisation

\begin{tabular}{|c|c|c|c|c|c|c|c|}
\hline & & \multicolumn{2}{|c|}{ Small } & \multicolumn{2}{|c|}{ Medium } & \multicolumn{2}{|c|}{ Large \& Very Large } \\
\hline & & Rank & Value & Rank & Value & Rank & Value \\
\hline \multirow{6}{*}{ 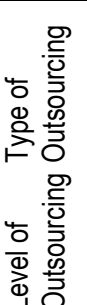 } & Selective Outsourcing & 1 & 0.833 & 1 & 0.843 & 1 & 0.966 \\
\hline & Transitional Outsourcing & 2 & 0.500 & 2 & 0.725 & 2 & 0.833 \\
\hline & Total Outsourcing & 1 & 0.833 & 3 & 0.568 & 3 & 0.400 \\
\hline & Tactical Outsourcing & 3 & 0.583 & 2 & 0.784 & 3 & 0.766 \\
\hline & Strategic Outsourcing & 1 & 0.833 & 1 & 0.843 & 2 & 0.800 \\
\hline & Transformational Outsourcing & 2 & 0.666 & 3 & 0.627 & 1 & 0.866 \\
\hline
\end{tabular}

\subsection{Success Vs Failure}

At the end of the survey the participating organisations were asked to classify themselves as having been successful at outsourcing, unsuccessful, or expressing a neutral outcome, and the data for these different cohorts enabled comparisons and contrasts to be made, between the different strengths and ranking of adoption, success factors, and type and level to be made (Tables 12, 13 \& 14).

The most prominent adoption factors amongst the successful cohort were found to be Operational Expertise, and wider knowledge and experience, whilst it was observed that the unsuccessful organizations saw operational expertise, capacity management and providing a legally binding contract as being less significant.

Based on further RII analysis, the most significant success elements of outsourcing, as perceived by the successful respondents, were: having a strategic vision \& plan and understanding the intended use of outsourcing, outsourcer understands the organization's goals \& objectives, conduct a need analysis prior to making the outsourcing decision. The ranking order of these success elements, amongst the unsuccessful cohort, were found to be fairly similar but experiencing weaker relative importance index values in most areas. 
Table 12 RII Analysis of reasons for outsourcing

\begin{tabular}{lcccc} 
& \multicolumn{2}{c}{ Successful } & \multicolumn{2}{c}{ Unsuccessful } \\
\cline { 2 - 5 } & Rank & Value & Rank & Value \\
\hline Access to a larger talent pool and a sustainable of skills & 4 & & 2 & 0.767 \\
\hline Operational expertise & 1 & 0.819 & 5 & .721 \\
\hline Capacity management & 4 & 0.781 & 8 & 0.688 \\
\hline Provide a legal binding contract & 5 & 0.774 & 12 & 0.660 \\
\hline Time zone & 11 & 0.645 & 14 & 0.605 \\
\hline Reduce time to market & 10 & 0.690 & 11 & 0.665 \\
\hline Improve quality & 7 & 0.761 & 4 & 0.726 \\
\hline Wider knowledge and experience & 2 & 0.794 & 1 & 0.795 \\
\hline Catalyst for change & 6 & 0.767 & 6 & 0.712 \\
\hline Cost restructuring & 3 & 0.787 & 3 & 0.735 \\
\hline Cost savings & 7 & 0.761 & 7 & 0.693 \\
\hline Reduce Customer pressure & 10 & 0.690 & 13 & 0.637 \\
\hline Risk Management & 10 & 0.690 & 10 & 0.674 \\
\hline Allows a wide range of businesses access to services & 8 & 0.748 & 9 & 0.684 \\
\hline
\end{tabular}

Table 13 RII Analysis of outsourcing success elements

\begin{tabular}{|c|c|c|c|c|}
\hline \multirow[b]{2}{*}{ Outsourcing success elements } & \multicolumn{2}{|c|}{ Successful } & \multicolumn{2}{|c|}{ Unsuccessful } \\
\hline & Rank & Value & Rank & Value \\
\hline Conduct a need analysis prior to making the outsourcing decision & 3 & 0.884 & 3 & 0.865 \\
\hline Having a strategic vision \& plan, and understanding the intended use of outsourcing & 1 & 0.916 & 2 & 0.865 \\
\hline Clearly defined terms \& conditions in the outsourcing contract & 5 & 0.865 & 1 & 0.898 \\
\hline Appropriate outsource selection procedures & 10 & 0.826 & 9 & 0.776 \\
\hline Ongoing management of the relationships \& communication & 8 & 0.839 & 11 & 0.721 \\
\hline Criteria are drawn up to measure the outsourcer's performance & 10 & 0.826 & 10 & 0.758 \\
\hline Properly drawn up contact & 9 & 0.832 & 7 & 0.837 \\
\hline Top management's support \& involvement & 4 & 0.871 & 7 & 0.837 \\
\hline Financial planning and analysis & 7 & 0.845 & 5 & 0.851 \\
\hline $\begin{array}{l}\text { Careful attention to the personnel issues \& conducting open communication with the affected } \\
\text { individual/group }\end{array}$ & 6 & 0.852 & 8 & 0.809 \\
\hline Seek to establish trust between organisation and outsourcer & 6 & 0.852 & 8 & 0.809 \\
\hline Outsourcer attains some form of certification such as ISO 9001, SEI, CMM rating & 11 & 0.787 & 10 & 0.758 \\
\hline Outsourcer understands the organisation's goals \& objectives & 2 & 0.903 & 4 & 0.860 \\
\hline Determine which areas of your company you would like to outsource & 10 & 0.826 & 6 & 0.842 \\
\hline
\end{tabular}

Table 14 RII Analysis of outsourcing types and levels

\begin{tabular}{|c|c|c|c|c|c|}
\hline & & \multicolumn{2}{|c|}{ Successful } & \multicolumn{2}{|c|}{ Unsuccessful } \\
\hline & & Rank & Value & Rank & Value \\
\hline \multirow{3}{*}{ 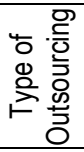 } & Selective Outsourcing & 1 & 0.881 & 1 & 0.906 \\
\hline & Transitional Outsourcing & 2 & 0.731 & 2 & 0.658 \\
\hline & Total Outsourcing & 3 & 0.548 & 3 & 0.496 \\
\hline \multirow{3}{*}{ 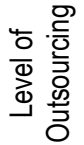 } & Tactical Outsourcing & 1 & 0.881 & 2 & 0.728 \\
\hline & Strategic Outsourcing & 2 & 0.731 & 1 & 0.852 \\
\hline & Transformational Outsourcing & 3 & 0.548 & 3 & 0.713 \\
\hline
\end{tabular}

\section{DISCUSSION AND CONCLUSIONS}

With long term trade restrictions being lifted in January 2016, meaning many Iranian enterprises will now able to engage in international business transactions and partnerships more freely, this research set out to establish which strategies Iranian enterprises must employ in order to practice successful outsourcing. The 31 successful Iranian enterprises that took part in this research, who represent the minority of small businesses already engaged in some level of outsourcing activity, were questioned about their reasons for adopting outsourcing, the type and level of outsourcing they had implemented, and their strategies for success. Factor analysis was adopted as the best method for clustering the adoption and success factors and RII was utilized in arranging variables on the basis of their significance. 
Based on the findings from this research it can be concluded that two of the primary drivers for adopting outsourcing, amongst those Iranian enterprises considered to be successful at this practice, were for seeking operational expertise and/ or cost restructuring purposes, which is similar to the findings of Valmohammadi (2012) and Beaumont and Sohal's investigation into the drivers behind outsourcing adoption in Australia, (Beaumont \& Sohal, 2004). The findings also indicated that the most important strategies for achieving success in outsourcing in Iran are having a strategic vision and plan, understanding the intended use of outsourcing, and understanding how outsourcing aligns with their organizations' goals and objectives. This contrasts somewhat with the findings of a study into IT/IS Outsourcing in Singapore, that suggested having a strategic vision and plan, and understanding the intend use of outsourcing, conducting a needs analysis prior to making the outsourcing decision, clearly defined terms and conditions, and top management's support and involvement are the most important success factor (Koh Ser Mui, 2003), although the importance of establishing a strategic vision and clear plan are underlined.

When analyzing the type and level of outsourcing being used by Iranian enterprises, selective and strategic outsourcing were found to be most popular amongst successful enterprises, which aligns with the findings of Lacity and Willcocks (2008) for outsourcing in a more general context. Finally, the sectors with the greatest level of outsourcing success were discovered to be construction, with no unsuccessful cases found, and the IT industry, with 10 of the $16(62.5 \%)$ participant companies experiencing success, juxtaposed to enterprises in the banking sector where no successful cases were reported.

Additionally, this research identified the fact that outsourcing factors differed, depending on the size of the organisation involved. In 'large and very large organisations', 'Cost Savings' and 'Cost Restructuring' were the most significant reasons for outsourcing, and 'Properly drawn up contact' and 'Top management's support \& involvement' were the key success factors. Transformational outsourcing was found to be the most commonly practiced level of outsourcing in these organisations. 'Operational expertise' was identified as the most significant reason for adopting outsourcing amongst Small and Medium organisations, with 'clearly defining terms and conditions in the outsourcing contract' being the most frequently cited factor for success, and 'selective and strategic outsourcing' identified as the most common type and level of outsourcing amongst this size group.

Outsourcing is a topic that has been studied in many environments through a number of social and economic lenses. The majority of previous outsourcing research has focused on more mature markets, such as: India, Australia, and China (Jain \& Natarajan, 2011; Beaumont \& Sohal, 2004; Koh Ser Mui, 2003), with only a handful of such studies investigating the practice from a Middle Eastern context. In different economic surroundings the importance for the various reasons for outsourcing, and those factors that lead to outsourcing success, can vary significantly. These new findings share similarities with previous outsourcing studies, conducted in other parts of the world, but have many key nuances that make them unique to Iranian enterprises. As such, the findings from this research have the potential to assist academic researchers, inform university teachers, and contribute to the formation of new policies in this area. They have clear implications for managers of Iranian enterprises, who are considering moving toward outsourcing and investigating new supply chains, and will help to deepen the understanding of economic developments in the Middle East. With the current high level of global interest for Iranian business and politics, it is predicted that many researchers will focus their attention on the developments arising in this region over the coming years, these findings will help address the gap that exists between practice and available literature in this particular domain.

There is little doubt that the economic sanctions placed on Iran have had a significant long-term effect on Iranian society, in areas such as health and culture (Shahabi, 2012), and as the sanctions are lifted economic conditions in Iran are expected to become far more stable than they have been in the past and, as trade grows, the standards of living for many Iranians are also expected to improve. An increase in the practice of outsourcing, with access to new markets and new cost savings and restructuring benefits being available to enterprises could be a contributing factor to that growth.

\subsection{Limitation and suggestion for future research}

Since the effects of outsourcing found amongst the many different Iranian industries are diverse, the survey sample seems slightly small in relation to the total residents of Tehran - Iran, but considering only a small number of enterprises are currently able to practice outsourcing, the survey sample size and a response rate that was received is considered to be fairly high.It is assumed that this high rate was achieved due to an understanding of local business customs and the personal delivery of the questionnaire.

One factor that did limit the data collection process, however, was the introduction of a new government law restricting research in Iran (Iran-students, 2011). This new government law was introduced during the data collection process for this research and prevented the researcher from being able to gather more data.

Despite obstacles encountered throughout the investigation, the information and knowledge gathered from the primary data, and academic literature, resulted in the researcher being able to present and analyse the findings with reference to the objectives of the research development.

While this research provides great insight of best outsourcing practices in Iranian enterprises, further research is encouraged. Advance research in measuring success, determining risk, and consequences of sanctions on outsourcing can present additional information in the field of outsourcing.

\section{NOTES/ENDNOTES}

1) Calculation of Relative Importance of Factors: Sambasivan and Yau (2007) used the relative importance index technique to establish the relative importance of the various causes and effects of delays in construction industries. A similar technique was adopted 
in this study. The five-point scale ranging from 1 (strongly disagree) to 5 (strongly agree) was adopted and altered to relative importance indices (RII) for all factors as follows:

$R \|=\frac{\sum W}{A^{*} N}$

Where ' $\mathrm{W}$ ' is the weighting each respondent gave to each concern (ranging from 1 to 5 ), ' $A$ ' is the greatest weight (i.e. 5 in this case), and ' $\mathrm{N}$ ' is the entire population of respondents. The 'RII' value had a range from 0 to 1 ( 0 not inclusive), with a higher value of RII indicating a more significant reason for, or successful element of, outsourcing.

\section{REFERENCES}

Assaf, S., Hassanain, M. A., Al-Hammad, A. M., \& Al-Nehmi, A. (2011). Factors Affecting Outsourcing Decisions of Maintenance Services in Saudi Arabian Universities. Property Management, 29(2), 195-212.

Beaumont, N., \& Sohal, A. (2004). Outsourcing in Australia. International Journal of Operations and Production Management, 24(7), 688-700.

Bell, S. (2013). Learning with Information Systems: learning cycles in information systems development. London: Routledge.

Borger, J., Macalister, T., \& Kamali Dehghan, S. (2015, April 3). End of Iran sanctions will open gates to companies keen to enlarge markets. The Guardian. Retrieved from http://www.theguardian.com/world/2015/apr/02/end-of-iransanctions-will-open-gates-to-companies-keen-to-enlargemarkets.

Brown, D., \& Wilson, S. (2005). The Black Book of Outsourcing. New Jersey: John Wiley \& Sons.

Christopher, M. (2016). Logistics and Supply Chain Management ( $5^{\text {th }}$ ed.). London: Pearson.

Cohen, S., \& Roussel, J. (2013). Strategic supply chain management: The five Core Disciplines for Top Performance ( $2^{\text {nd }}$ ed.). New York: McGraw-Hill.

Crooks, E. (2012, April 2). GE takes \$1bn risk in bringing jobs home. Financial Times. Retrieved from http://www.ft.com/intl/cms/s/0/21a46546-78f1-11e1-88c500144feab49a.html\#axzz2B6FpmxyN.

Ellram, L. M., Tate, W., \& Petersen, K. J. (2013). Offshoring and Reshoring: An Update on the Manufacturing Location Decision. Journal of Supply Chain Management, 49(2), 1422.

Fowler Jr, F. J. (2014). Survey research methods ( $5^{\text {th }}$ ed.). Boston: Sage Publications Inc.

Gonzalez, R., Gasco, J., \& Llopis, J. (2005). Information Systems Outsourcing Success Factors: A Review and Some Results. Information Management \& Computer Security, 13(5), 399418.

Hansen, M. W., Muller, H. S., \& Pottenger, E. (2008). Towards Developing Country Firm Perspective on Outsourcing. Strategic Outsourcing: An International Journal, 1(3), 210229.

Holt, G. D. (2014). Asking questions, analysing answers: relative importance revisited. Construction Innovation, 14(1), 2-16.

Ilias, S. (2010, April 22). Iran's Economic Conditions: U.S. Policy Issues. Federation of American Scientists. Retrieved from https://www.fas.org/sgp/crs/mideast/RL34525.pdf.

Iran: Students Abroad Barred from Iran-related Research. (2011, March 10). Eurasia Review. Retrieved from http://www.eurasiareview.com/10032011-iran-studentsabroad-barred-from-iran-related-research.

Jain, R. K., \& Natarajan, R. (2011). Factors influencing the outsourcing decisions: a study of the banking sector in India.
Strategic Outsourcing: An International Journal, 4(3), 294 322.

Johnson, C. (2016, January 28). Airbus signed \$25bn deal to sell 118 to Iran. $B B C$. Retrieved from http://www.bbc.com/news/business-35434483.

Jones, W. O. (2009). Outsourcing in China: opportunities, challenges and lessons learned: Industry Insight. Strategic Outsourcing: An International Journal, 2(2), 187-203.

Kamyabi, Y., \& Devi, S. (2011). An Empirical Investigation of Accounting Outsourcing in Iranian SMEs: Transaction Cost Economics and Resource-Based Views. International Journal of Business and Management, 6(3), 81-94.

Kang, M., Wu, X., \& Hong, P. (2009). Strategic outsourcing practices of multi-national corporations (MNCs) in China. Strategic Outsourcing: An International Journal, 2(3), 240256.

Katzman. K. (2016, January 21). Iran Sanctions. Federation of American Scientists. Retrieved from https://www.fas.org/sgp/crs/mideast/RS20871.pdf.

Koh Ser Mui, A. (2003). Investigation of IT/IS Outsourcing in Singapore (Unpublished master's thesis). Dept. of Software Engineering and Computer Science, Sweden.

Lacity, M. C., \& Rottman, J. W. (2009). Effects of offshore outsourcing of information technology work on client project management. Strategic Outsourcing: An International Journal, 2(1), 4-26.

Lacity, M. C., \& Willcocks, L. P. (2008). Information Systems and Outsourcing: Studies in Theory and Practice. New York: Palgrave Macmillan.

Lacity, M. C., Willcocks, L. P., \& Rottman J. W. (2008). Global outsourcing of back office services: lessons, trends, and challenges. Strategic Outsourcing: An International Journal, 1(1), 13-34.

Lysons, K., \& Farrington, B. (2012). Purchasing and Supply Chain Management $\left(8^{\text {th }}\right.$ ed.). Hampshire: Pearson Education Limited.

Manning, S., Massini, S., \& Lewin, A. Y., (2008). A Dynamic Perspective on Next-Generation Offshoring: The Global Sourcing of Science and Engineering Talent. Academy of Management Perspectives, 22(3), 35-54.

Marquez-Ramos, L. \& Martinez-Zarzoso, I. (2014). Trade in Intermediate goods and Euro-Med Production Networks. Middle East Development Journal, 6(2), 215-231.

Ministry of Economic Affairs and Finance (2009, February 2). Decree of Supreme Council for Implementation of the General policies of Principle (44) of the Constitution. Iran Privatization Organization. Retrieved from http://www.en.ipo.ir/index.aspx ?fkeyid=\&siteid=83\&pageid $=1305$.

Mendes, L., \& Lourenço, L. (2014). Factors that hinder quality improvement programs' implementation in SME: Definition of a taxonomy. Journal of Small Business and Enterprise Development, 21(4), 690-715.

Miah, S. J., Ahsan, K., \& Msimangira, K. A. B., (2014). An Approach of Purchasing Decision Support in Healthcare Supply Chain Management. Operations and Supply Chain Management: An International Journal, 6(2), 43-53.

Mishra, D., \& Mahanty, B. (2014). The effect of onsite-offshore work division on project cost, schedule, and quality for reengineering projects in Indian outsourcing software industry. Strategic Outsourcing: An International Journal, 7(3), 198225.

Modarress, B., Ansari, A., \& Thies, E. (2016). Outsourcing in the Persian Gulf Petroleum Supply Chain. Strategic Outsourcing: An International Journal, 9(1), 2-21.

Msimangira K. A. B., \& Techa, A. P., (2014). Global Supply Chain Practices and Problems Facing Developing Countries: A Study in Tanzania. Operations and Supply Chain Management: An International Journal, 7(3), 130-138. 
Nasralla, S., \& Shehan, M. (2015, July 23). Iran eyes $\$ 185$ billion oil and gas projects after sanctions. Reuters. Retrieved from http://www.reuters.com/article/2015/07/23/us-iran-nuclearindustry-idUSKCNOPXOXQ20150723.

Oshri, I., Kotlarsky, J., \& Willcocks, L. P. (2015). The Handbook of Global Outsourcing and Offshoring ( $3^{\text {rd }}$ Ed.). New York: Palgrave Macmillan.

Paivar, A. (2015, July 27). Investing in Iran after the lifting of sanctions. BBC Business. Retrieved from http://www.bbc.com/news/business-33639124.

Pettersson, A. I., \& Segerstedt, A. (2013). To Evaluate Cost Saving in a Supply Chain: Two Examples from Ericsson in the Telecom Industry. Operations and Supply Chain Management: An International Journal, 6(3), 94-102.

Quinn, J. B. (2000). Outsourcing Innovation: The New Engine of Growth. Sloan Management Review, 41(4), 13-28.

Rasli Muslimen, A. S. Z. A., Norzima Zulkifli, R. M. Y., Yusof Ismail, M., \& Abu Baker, N. (2012). An Exploratory Study on the Critical Success Factors for Design Capabilities Development. Operations and Supply Chain Management: An International Journal, 5(1), 14-26.

Rezaei, B. A. (2009). Evaluation of Privatisation in Iran. Tehran: Kouhsar Publishing.

Sambasivan, M., \& Yau, W. S. (2007). Causes and Effects of Delays in Malaysian Construction Industry. International Journal of Project Management, 25(5), 517-526.

Saunders, M. N. K., Lewis, P. \& Thornhill, A. (2015). Research Methods for Business Students ( $7^{\text {th }}$ ed.). London: Prentice Hall.

Schniederjans, M., Schniederjans, A. M., \& Schniederjans, D. G. (2007). Outsourcing Management Information Systems, Idea Group Inc. (IGI). Hershey, PA, 1-42, 177, 200-224.

Sedahi, M. S., \& Davarzani, H. (2010). Privatisation and Outsourcing: Successful and Failed Samples. Tehran: The Institute for Trade Studies \& Research,

Sepehri, M. (2013). Strategic Selection and Empowerment of Supplier Portfolios Case: Oil and Gas Industries in Iran. Procedia - Social and Behavioral Science, 74, 51-60.

Seth, M. Goyal, D. P., \& Kiran, R. (2015).Development of a Model for Successful Implementation of Supply Chain Management Information System in Indian Automotive Industry, SAGE Publication, 19(3), 248-262.

Shahabi, M. (2012, December 11). Sanctions are destroying Iranian society. Global Research. Retrieved from http://www.globalresearch.ca/sanctions-are-destroyingiranian-society/5315115.

Sirkin, H. L., Zinser, M., Hohner, D., \& Rose, J. (2012). U.S .manufacturing nears the tipping point', Boston Consulting Group Study. Retrieved from http://doingwhatmatters.cccco.edu/portals/6/docs/US\%20Mf g\%20Nears\%20Tipping\%20Point.pdf.

Slack, N., Nrandon-Joes, A. Johnston, R., \& Betts, A. (2015). Operations and Process Management $\left(4^{\text {th }}\right.$ ed.). London: Pearson.

Solakivi, T., Töyli, J., Engblom, J., \& Ojala, L. (2011). Logistics outsourcing and company performance of SMEs: Evidence from 223 firms operating in Finland. Strategic Outsourcing. An International Journal, 4(2), 131-151.

UN Security Council endorses Iran nuclear deal (2015, July 20), $B B C$ News. Retrieved from http://www.bbc.com/news/world-middle-east-33594937.

Valmohammadi, C. (2012). Investigating Outsourcing Implementation in Iranian Organizations. Research Journal of Applied Sciences Engineering and Technology, 4(3), 186-190.

Valmohammadi, C. (2012). Investigating Supply Chain Management Practices in Iranian Manufacturing Organization. Operations and Supply Chain Management: An International Journal, 6(1), 36-42.

Willcocks, L. P. (2010). The Next Step for CEO: Moving ITEnabled Services Outsourcing to the Agenda. Strategic Outsourcing: An International Journal, 1(1).

Willcocks, L. P, (2011). Machiavelli, management and outsourcing: still on the learning curve. Strategic Outsourcing: An International Journal, 4(1), 5-12.

Yukhananov, A., Grant, P., Croft, A., \& Nicholas, M. (2015, April 2). Factbox: Sanctions Imposed on Iran. Reuters. Retrieved

from http://www.reuters.com/article/2015/04/02/us-iran-nuclearsanctions-factbox-idUSKBNOMT02420150402.

Zomorrodi, A. (2014). Critical Success Factors for Outsourcing Strategy Implementation: Iran Automotive Industry. Asian Journal of Business \& Management, 2(2), 107-113.

Dr. Mohammadreza Akbari is a lecturer, in Operations Management, Logistics and Supply Chain Management, from the Australian Institute of Business. He holds a Doctorate in Business Administration (DBA) in Business and Management (Supply Chain Management) from the Victoria University, an MBA in International Business and a Bachelor of Business Administration. His research interests are in the areas of logistics and supply chain management, operations management, strategic management, outsourcing, and business process re-engineering.

Dr. John L. Hopkins is a Senior Lecturer, in Supply Chain and Logistics Management, from Swinburne University of Technology. He has worked extensively in industry, for organisations such as General Motors and Cadbury, in addition to academic institutions in the UK, Ireland, USA and Australia. John's time in industry has been critical to his academic career and he enjoys working at the interface of academic theory/knowledge and real-world industry practice. 